УДК $630 * 232.32+630 * 811.1$

DOI: $10.37482 / 0536-1036-2020-5-81-89$

\title{
THE EFFECTIVENESS OF LOW FREQUENCY ELECTROMAGNETIC FIELD AND HYDROGEL INFLUENCE ON SURVIVAL RATE AND GROWTH OF RED OAK (Quercus rubra L.) ANNUAL SEEDLINGS
}

\author{
A.I. Smirnov ${ }^{1}$, Candidate of Agriculture; ORCID: $\underline{\text { https://orcid.org/0000-0001-9530-6210 }}$ \\ F.S. Orlov ${ }^{1}$, Candidate of Agriculture; ORCID: https://orcid.org/0000-0002-8772-4428 \\ P.A. Aksenov', Candidate of Agriculture, Assoc. Prof.; ResearcherID: H-1352-2019, \\ ORCID: https://orcid.org/0000-0002-1716-7726 \\ Yu.V. Yaskov, Director of Donskoy Leskhoz; ORCID: https://orcid.org/0000-0002-2140-9169 \\ ${ }^{1}$ OOO “Raznoservis", Likhov per., 10, Moscow, 127051, Russian Federation; \\ e-mail: 364-27-37@mail.ru, ap-6@yandex.ru \\ ${ }^{2}$ Mytischi Branch of Bauman Moscow State Technical University, ul. 1-ya Institutskaya, 1, \\ Mytischi, Moscow Region, 141005, Russian Federation; e-mail: axenov.pa@mail.ru, \\ forestmaster@yandex.ru \\ ${ }^{3}$ GAU "Donskoy Leskhoz", Forestry Department of the Lipetsk Region, ul. Mira, 19, \\ s. Donskoye, Zadonskiy District, Lipetsk Region, 99240, Russian Federation; \\ e-mail: forester48@mail.ru
}

This work presents the results of a research that was conducted in the Donskoy Leskhoz nursery of the Forestry Department of the Lipetsk Region. The purpose of the research is to determine the effectiveness of the influence of a low-frequency electromagnetic field and the hydrogel "Evabiona" on the survival rate of red oak annual seedlings grown in open ground of the nursery. This research presents the technology for creating red oak planting material with increased survival indices of test samples and their biometric parameters: seedling height, seedling diameter at a root collar, weight of roots and aboveground part in the air-dry condition after drying for 15 days. Treatment of red oak one-year old seedlings with a low frequency electromagnetic field was carried out according to the author's technology POSEP - pre-sowing treatment of seeds and seedlings with an electromagnetic field. The hydrogel, a polymer water-retaining agent that absorbs and retains a large amount of moisture in the rhizosphere of plants, was applied to soil in the experimental research. The ability of the hydrogel granules to swell-compression improves the structure and drainage of soils, boosting the conditions of aeration and filtration of water, and maintains its waterretaining properties for several years. The research results indicate a clear positive effect of treatment with a low-frequency electromagnetic field and the hydrogel, as there was a significant increase in the survival rate of the test samples of oak seedlings in relation to the control samples. Also within the framework of the research a comparative histometric analysis of cross sections of control and test stems of oak seedlings was carried out late in the growing season at the laboratory of the Department of Forest Crops, Selection and Dendrology of the Mytishchi Branch of the Bauman Moscow State Technical University. The results of this research showed that a low-frequency electromagnetic field and the hydrogel can influence on the anatomical structure of seedlings, improving their quality characteristics. Thus, pre-sowing treatment of oak seedlings with a low-frequency electromagnetic field and the use of the hydrogel showed the effectiveness of these techniques in increasing the survival rate of seedlings and obtaining high-quality planting material of red oak in forest nurseries.

For citation: Smirnov A.I., Orlov F.S., Aksenov P.A., Yaskov Yu.V. The Effectiveness of Low Frequency Electromagnetic Field and Hydrogel Influence on Survival Rate and Growth of Red Oak (Quercus rubra L.) Annual Seedlings. Lesnoy Zhurnal [Russian Forestry Journal], 2020, no. 5, pp. 81-89. DOI: 10.37482/0536-1036-2020-5-81-89

Keywords: low frequency EMF, POSEP technology, hydrogel, red oak seedlings, histometric analysis. 


\section{Introduction}

Oak forests of our country are an important component of natural ecosystems. However, due to the large anthropogenic load on the forests in the Central region of the European part of Russia, the area of oak plantations has been greatly reduced. According to experts, this problem can be solved by introducing new, fastgrowing and economically valuable introduced species into the process of artificial reforestation of broad-leaved species. They include red oak (Quercus rubra L.), natural habitat of which are broad-leaved forests of North America [1]. Red oak is most prevalent of all introduced hardwood species in the European part of Russia. Although it is inferior in wood quality to pedunculate oak (Quercus robur L.), but still it has a number of advantages. It is known that red oak is moderately photophilous, undemanding to soil, quite hardy, resistant to powdery mildew, not damaged by the green oak moth (Tortrix viridana), has soil-improving properties and grows by $10-50 \%$ faster than pedunculate oak (Quercus robur L.). The age of the main felling of red oak stands can be reduced by 1.5 times, relative to pedunculate oak (Quercus robur L.) [8]. Due to its unique decorative properties, red oak is widely used in landscape design [5]. These qualities of red oak make it a promising forestforming species in the zone of coniferous broad-leaved forests. Therefore, studies of this tree species are relevant nowadays. The use of an electromagnetic field (EMF) and the hydrogel Evabiona for growing high-quality planting material is a little studied area in the Russian forestry sector. Although in forest seed production, we have used the treatment of coniferous seeds, and later seedlings, with EMF since 2012. As a result of the studies, carried out both in laboratories and in forest nurseries, a simple and environmentally friendly technology of pre-sowing treatment of seeds and seedlings with an electromagnetic field (POSEP) [11] was developed and the "RostAktiv" device (a low-frequency EMF generator) was created [4, 6, 10, 13].

Hydrogel is a polymer water-retaining agent that is introduced into the soil, absorbs and retains water and dissolved nutrients. It was also used in the research. Hydrogel tends to easily release the accumulated water, gradually providing it to plants. When properly applied, it retains fertilizers, keeping them in an accessible zone for plant roots, improves the water-physical soil properties $[2,17]$ and provides the most favorable conditions for growth and development of tree species in the first years after planting [18]. Further study (2013-2019) of the influence of la ow-frequency EMF and the hydrogel included treatment of seeds and growing seedlings of coniferous species in forest nurseries (Scots pine and Norway spruce). The results of these studies indicate the effectiveness of the POSEP technology and the use of the hydrogel in the treatment of both seeds and seedlings of the main forest-forming species [14, 20]. The presented work is interesting by the reason that such experiments have not been carried out on seedlings of deciduous tree species before.

\section{Research objects and methods}

The research was carried out in the Donskoy Leskhoz nursery of the Forestry Department of the Lipetsk Region in 2019. Bareroot annual seedlings of red oak were the research object. In April 2019 control and experiment plantings of red oak seedlings were laid out on a plot of $150 \mathrm{linm}$ of a planting bed in order to study the effect of a low-frequency EMF and the hydrogel on their survival rate. Three seedling options were compared: Control - untreated seedlings, 50 pcs; Experiment 1 seedlings treated with EMF, 50 pcs; Experiment 2 - seedlings treated with EMF and the hydrogel, 50 pcs. 
Seedlings for Experiments 1 and 2 were treated using the POSEP technology with the low frequency generator "Rost-Aktiv" (frequency - $16 \mathrm{~Hz}$; increasing magnetic field induction value from 0.4 to $2.0 \mathrm{mT}$; exposure - $11 \mathrm{~min}$ ) according to the research procedure before planting in holes $[3,7,12,16]$. Seedlings were planted using the Kolesov's planting iron with a planting step of $1 \mathrm{~m}$. In Experiment 2, the planting holes were pre-treated with the hydrogel swollen in water (at a rate of 2 $\mathrm{g}$ of the dry hydrogel per hole), after that seedlings treated with EMF were planted. At the end of September 2019, we made records on the seedlings established in the experimental and control areas and carried out biometric measurements of them (fig. 1).

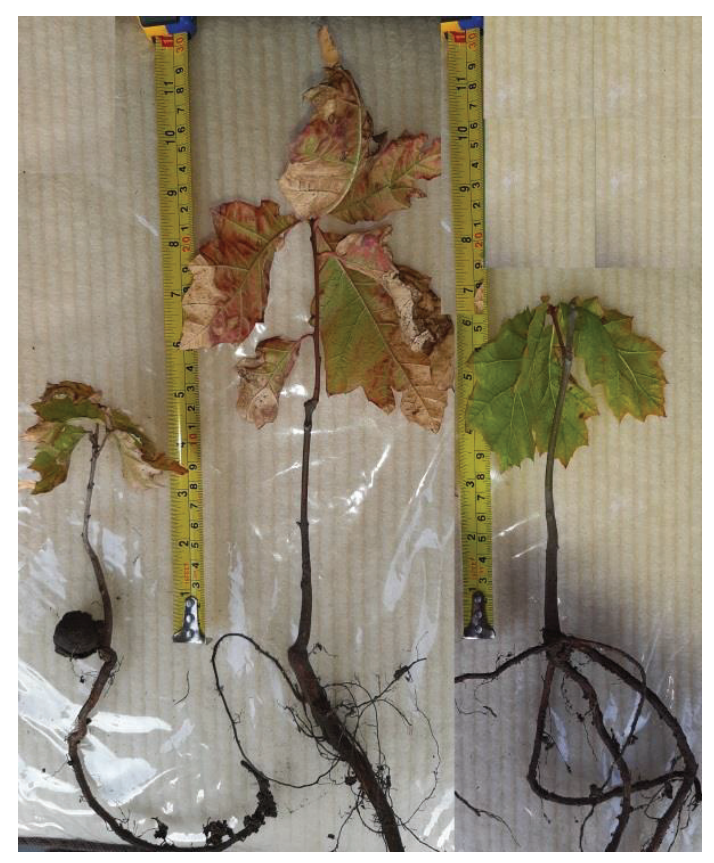

Fig. 1. Records on the seedeings from left to right: Control, Experiment 2 and Experiment 1

At the same time, Control and Experiment seedlings were lifted with maximum integrity of the root system for in-depth studies in the laboratory of the Department of Forest Crops, Selection and Dendrology of the Mytishchi Branch of the Bauman Moscow State Technical University. The following biometric parameters were measured: seedling height, seedling diameter at a root collar, roots weight and the aboveground part in the air-dry condition after drying for 15 days. The scales Acom JW1 were used to determine the average weight of seedling parts.

The following technique was used for the histometric analysis of cross sections: $1-2 \mathrm{~cm}$ sections of stems with root collars were cut from the seedlings, and then they were exposed to the action of a softening alcohol-glycerine mixture (component ratio 1:1) for 10 days at a temperature of $25-30{ }^{\circ} \mathrm{C}$. Later on, cross sections were obtained using MS-2 microtome and stained in accordance with the standard method [15]. Temporary glycerine preparations were produced in accordance with the procedure described in reference [19]. Microscopy was carried out in the direct light-field and polarization modes using a research biological microscope 
Jenaval (Carl Zeiss) equipped with an eyepiece micrometer and polarizers. The following microlenses were used: GF-Plan 3.2/0.06/ $/$ /-; GF-Plan 12.5/0.25/ $/$ /-;

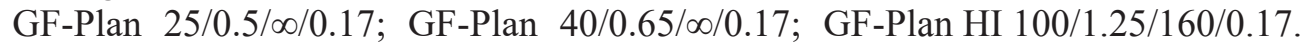
Images of wood cross sections were obtained using photomicrographic attachment.

To verify the reliability of the results obtained, we followed standard methods of statistical processing [9] and used Microsoft Excel software.

\section{Research results and discussion}

An analysis of the survival rate of seedlings in autumn 2019 showed a significant superiority of Experiment options over the Control (table 1).

Table 1

Characteristics of the survival rate of red oak seedlings treated with EMF and the hydrogel

\begin{tabular}{|c|l|c|c|c|}
\hline No. & $\begin{array}{c}\text { Experiment } \\
\text { options }\end{array}$ & $\begin{array}{c}\text { Number of recorded } \\
\text { seedlings during } \\
\text { planting }\end{array}$ & $\begin{array}{c}\text { Number of established seedlings } \\
\text { (recorded in September, 2019) }\end{array}$ & $\begin{array}{c}\text { Survival rate, \%, } \\
\pm \text { error of the } \\
\text { proportion, \% }\end{array}$ \\
\hline 1 & Control & 50 & 14 & $28 \pm 6.4$ \\
\hline 2 & Experiment 1 & 50 & 24 & $48 \pm 7.1$ \\
\hline 3 & Experiment 2 & 50 & 32 & $64 \pm 6.8$ \\
\hline
\end{tabular}

The results of studying the effect of EMF and the hydrogel on the survival rate of red oak seedlings grown in open ground of the nursery in the dry summer of 2019 show that the best option is the treatment with EMF and the hydrogel during planting (table 1). The observed difference can be explained by the stimulating effect of EMF with the joint long-term protective action of the hydrogel on the subsequent rhizogenesis after transplantation and absorption of solutions by roots in the post-stress period. Also, the treatment with EMF and the hydrogel had an impact on the biometric parameters of oak seedlings (table 2).

Table 2

Average biometric parameters of oak seedlings treated with EMF and the hydrogel (sampling size $-20 \mathrm{pcs} ; \alpha=0.05 ; t_{s t}=2.024$ )

\begin{tabular}{|c|l|c|c|c|c|}
\hline \multirow{2}{*}{ No. } & \multicolumn{1}{c|}{$\begin{array}{c}\text { Experiment } \\
\text { options }\end{array}$} & $\begin{array}{c}\text { Seedling height, } \\
\mathrm{cm} \\
\left(M \pm m_{M}\right)\end{array}$ & $\begin{array}{c}\text { Root collar } \\
\text { diameter, mm } \\
\left(M \pm m_{M}\right)\end{array}$ & $\begin{array}{c}\text { Roots mass, } \\
\left(M \pm m_{M}\right)\end{array}$ & $\begin{array}{c}\text { Trunks mass, } \\
\mathrm{g}\left(M \pm m_{M}\right)\end{array}$ \\
\hline \multirow{2}{*}{1} & $12.5 \pm 0.49$ & $4.0 \pm 0.09$ & $4.2 \pm 0.22$ & $1.24 \pm 0.03$ \\
\hline \multirow{2}{*}{2} & Control & 100 & 100 & 100 & 100 \\
\cline { 2 - 6 } & \% of control & $14.5 \pm 0.42$ & $5.5 \pm 0.22$ & $11.9 \pm 0.39$ & $3.29 \pm 0.10$ \\
\cline { 2 - 6 } & Experiment 1 & 116 & 137 & 283 & 265 \\
\hline \multirow{2}{*}{3} & $t_{\text {calculated }}$ Experiment 2 & $21.0 \pm 0.54$ & $4.5 \pm 0.16$ & $9.57 \pm 0.34$ & $3.89 \pm 0.25$ \\
\cline { 2 - 6 } & $\%$ of control & 168 & 112 & 227 & 313 \\
\cline { 2 - 6 } & $t_{\text {calculated }}$ & 11.66 & 2.72 & 13.27 & 10.52 \\
\hline
\end{tabular}

Based on the results of autumn calculations, the average biometric parameters of red oak seedlings were compared in all experiment options: Experiment 1; Experiment 2; Control. The data in table 2 indicate that the treatment of seedlings in Experiment 2 exceeded Control by every measure, so height of the Experiment samples exceeded the Control by $68 \%$. This is a substantial difference considering 
that the seedlings were grown in open ground without watering and care. Also, at the end of the growing season, a comparative histometric analysis of cross sections of the Control and Experiment stems of oak seedlings was carried out in the laboratory of the Department of Forest Crops, Selection and Dendrology of the Mytishchi Branch of the Bauman Moscow State Technical University. The results of this study are shown in table 3 .

Table 3

Average histometric parameters of oak seedlings treated with EMF and the hydrogel (sampling size $-10 \mathrm{pcs} ; \alpha=0.05 ; t_{s t}=2.1$ )

\begin{tabular}{|c|l|c|c|c|}
\hline \multirow{2}{*}{ No. } & \multicolumn{1}{|c|}{$\begin{array}{c}\text { Experiment } \\
\text { options }\end{array}$} & $\begin{array}{c}\text { Core diameter, } \mathrm{mm} \\
\left(M \pm m_{M}\right)\end{array}$ & $\begin{array}{c}\text { Xylem ring width, mm } \\
\left(M \pm m_{M}\right)\end{array}$ & $\begin{array}{c}\text { Secondary wood ves- } \\
\text { sels diameter, } \mu \mathrm{m} \\
\left(M \pm m_{M}\right)\end{array}$ \\
\hline \multirow{2}{*}{1} & Control & $1.51 \pm 0.087$ & $0.86 \pm 0.034$ & $18.7 \pm 0.91$ \\
\cline { 2 - 5 } & $\%$ of control & 100 & 100 & 100 \\
\hline \multirow{3}{*}{2} & Experiment 1 & $1.79 \pm 0.122$ & $1.43 \pm 0.074$ & $19.6 \pm 0.99$ \\
\cline { 2 - 5 } & $\%$ of control & 118 & 166 & 105 \\
\cline { 2 - 5 } & $t_{\text {calculated }}$ & 1.87 & 6.99 & 0.67 \\
\hline \multirow{2}{*}{3} & Experiment 2 & $1.55 \pm 0.065$ & $1.31 \pm 0.069$ & $21.7 \pm 1.08$ \\
\cline { 2 - 5 } & $\%$ of control & 103 & 152 & 116 \\
\cline { 2 - 5 } & $t_{\text {calculated }}$ & 0.37 & 5.85 & 2.12 \\
\hline
\end{tabular}

According to table 3 we made conclusions. The size of the core of the compared groups in the Experimental options exceeds the Control. The total xylem ring width in Experiments 1 and 2 significantly exceeds the Control width. The wood radial growth at the level of a root collar has the maximum values in Experiment 1. When comparing the average diameters of the secondary xylem vessels in different options of the experiment, there is a tendency to increase the average diameter of the vessel segment in the series Control - Experiment 1 - Experiment 2.

Comparative anatomical study of seedlings from three options of the experiment revealed the features of the stem structure at the level of the root collar according to the study of cross sections.

In general, the secondary xylem in all considered experiment options has common juvenile features. It is particularly worth noting the high degree of parenchyma formation on the last radial increment of seedlings. It is represented by both multiple single-row wood rays, and a high content of metatracheal starch-bearing parenchyma (fig. 2).

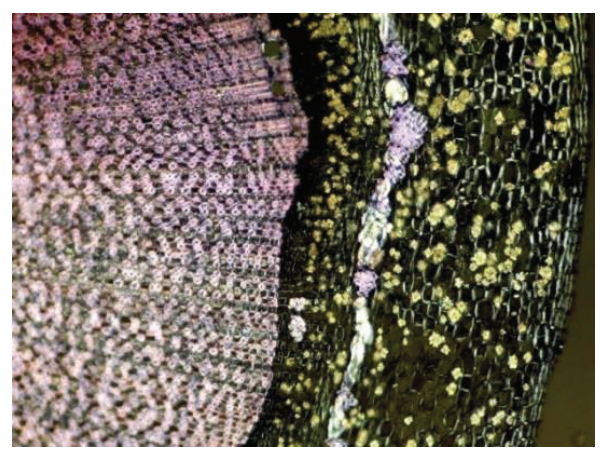

Fig. 2. Cross section of oak seedling in experiment

2 in the mode of crossed Nichols (microlens GF-Plan 12.5/0.25/ळ/-) 
The zone of highly parenchymatized wood is on the right. Multiple oxalate crystals and a solid light fiber (a glued ring) are observed in the cortical ring (fig. 2).

The core of all options contains a fair amount of small starch grains. There is a tendency to an increase in the occurrence of starch in the core cells in the Experiment options compared with the Control (fig. 3).

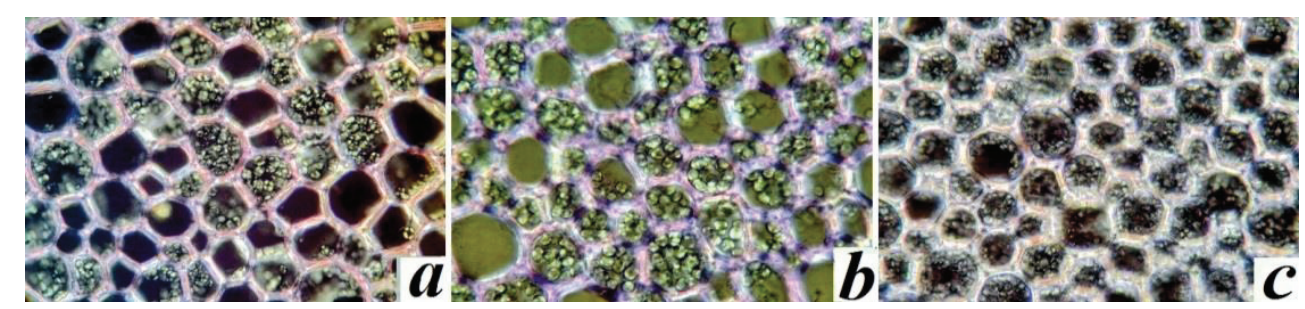

Fig. 3. Cross sections of the core of oak seedlings in the mode of partially crossed Nichols (microlens GF-Plan 40/0.65/oo/0.17): $a$-Control; $b$ - Experiment 1; $c$ - Experiment 2

The width of the secondary xylem layer is much larger in the options with EMF treatment. There is a high degree of order in radial chains of vessel lumen with an increase in the annual ring (fig. 4).

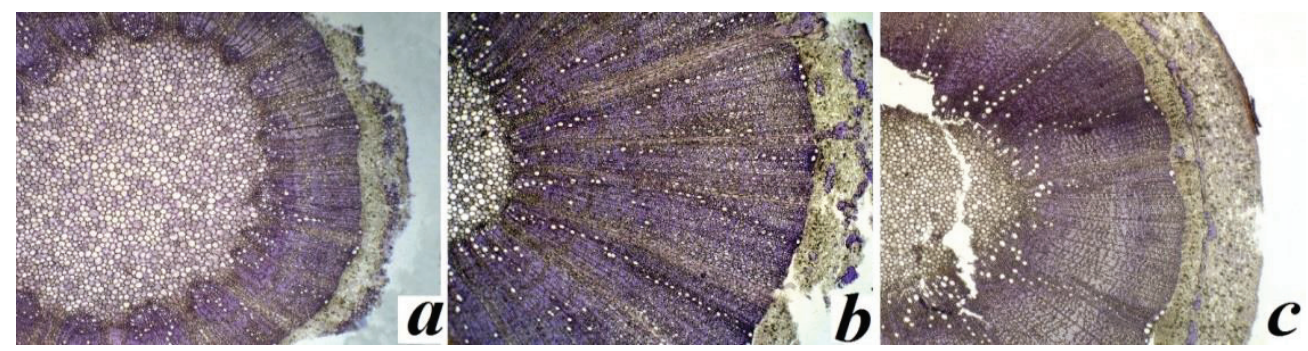

Fig. 4. Cross sections of oak seedling stems at one magnification (microlens GF-Plan 3.2/0.06/o/-, gentian violet staining): $a$ - Control; $b$ - Experiment $1 ; c-$ Experiment 2

The bark width is also of great importance in plants treated with EMF. This preserves the integrity of the bark inner ring formed by alternating sections of primary bast fibers and clusters of stone cells. The bulk of the primary cortex is a thinwalled parenchyma containing a large number of small druses and single crystals of calcium oxalate, well detected in the polarization mode (fig. 2). Aggregate rays, as a rule, end in the bark with the formation of large zones of sclerification and calcification.

\section{Conclusion}

The survival rate and growth of red oak seedlings in the selected area of the Donskoy Leskhoz nursery of the Forestry Department of the Lipetsk Region were evaluated as a result of the research. At the end of the growing season during the autumn records it was found that oak seedlings treated with EMF and planted in planting holes with the introduction of the hydrogel swollen in water have shown the best results in the survival rate and growth. It should also be noted that the treatment with EMF and the hydrogel had a positive effect on the internal structure of seedlings. This can improve the wood quality. Thus, the treatment of seedlings with a low-frequency EMF in combination with the use of the hydrogel promote the production of planting material with better parameters that will undoubtedly give a positive economic effect. 
Based on the research results, it is possible to assume the feasibility of processing the red oak planting material with a low-frequency EMF and the hydrogel in the creation of crops. And the use of hydrogels in forest management of the Russian Federation can be attributed to the number of promising reclamation measures in creation of artificial forest plantations.

\section{REFERENCES}

1. Булыгин Н.Е., Ярмишко В.Т. Дендрология. М.: МГУЛ. 2001. 528 с. [Bulygin N.E., Yarmishko V.T. Dendrology. Moscow, MGUL Publ., 2001. 528 p.].

2. Данилова Т.Н., Козырева Л.В. Возможности использования гидрогелей для управления водообеспеченностью полей // Плодородие. 2008. № 6. C. 24-25. [Danilova T.N., Kozyreva L.V. The Possibility of Hydrogel Application for Management of Field Water Supply. Plodorodie, 2008, no. 6, pp. 24-25].

3. Кораблев P.A. Влияние физических факторов на свойства семян и рост сеянцев сосны обыкновенной и березы повислой: дис. ... канд. с.-х. наук. Воронеж. 2003. 201 c. [Korablev R.A. Influence of Physical Factors on the Properties of Seeds and Growth of Seedlings of Scots Pine and Silver Birch: Cand. Agric. Sci. Diss. Voronezh, 2003. 201 p.].

4. Куликова Н.Н. Экологические аспекты действия низкочастотного электромагнитного поля на биологические объекты растительного происхождения: дис. ... канд. биол. наук. Москва, 2006. 145 с. [Kulikova N.N. Ecological Aspects of the Action of a Low-Frequency Electromagnetic Field on Biological Objects of Plant Origin: Cand. Biol. Sci. Diss. Moscow, 2006. 145 p.].

5. Новикова У.Е. Опыт выращивания сеянцев дуба красного в условиях Подмосковья // Вестн. МГУЛ - Лесн. вестн. 2010. № 5. С. 52-54. [Novikova U.E. The Experience of the Cultivation of the Seedlings of the Red Oak in Conditions of Moscow Region. Vestnik Moskovskogo gosudarstvennogo universiteta lesa - Lesnoy vestnik [Forestry Bulletin], 2010, no. 5, pp. 52-54].

6. Патент № 155132 Российская Федерация, МПК А 01 С 1/00. Устройство для предпосевной обработки посевного материала: опубл. 20.09.2015 / Смирнов А.И., Орлов Ф.С. Бюл. № 26. 6 с. [Smirnov A.I., Orlov F.S. Device for Pre-Sowing Processing of Seed Material. Patent RF no. RU 155132 U1, 2015. 6 p.].

7. Патент № 2591969 Российская Федерация, МПК А 01 С 1/00. Способ предпосевной обработки семян и устройство для его осуществления опубл. 20.07.2016 / Смирнов А.И., Орлов Ф.С.: Бюл. № 20. 7 с. [Smirnov A.I., Orlov F.S. Method of Preplanting Treatment of Sowing Material and Device Therefor. Patent RF no. RU 2591969 C1, 2016. 7 p.].

8. Редько Г.И., Мерзленко М.Д., Бабич Н.А., Трещевский И.В. Лесные культуры и защитное лесоразведение / под общей ред. Г.И. Редько. СПб.: СПбГЛТА, 1999. 419 с. [Red'ko G.I., Merzlenko M.D., Babich N.A., Treshchevskiy I.V. Forest Plantations and Protective Afforestation. Ed. by G.I. Red'ko. Saint Petersburg, SPbGLTA Publ., 1999. 419 p.].

9. Свалов Н.Н. Вариационная статистика. 4-е изд., стер. М.: МГУЛ, 2001. 80 с. [Svalov N.N. Variation Statistics. Moscow, MGUL Publ., 2001. 80 p.].

10. Смирнов А.И. Влияние электромагнитных полей низкой частоты на рост сеянцев сосны обыкновенной // Вестн. МГУЛ-Лесн. вестн. 2014. № 4. С. 52-56. [Smirnov A.I. The Influence of Electromagnetic Pour on Low Frequency to an Increase in the Seedlings of the Pine Tree of Usual. Vestnik Moskovskogo gosudarstvennogo universiteta lesa - Lesnoy vestnik [Forestry Bulletin], 2014, no. 4, pp. 52-56].

11. Смирнов А.И. Влияние низкочастотного электромагнитного поля на всхожесть семян и рост сеянцев сосны обыкновенной в питомниках зоны смешанных лесов: дис. ... канд. с.-х. наук. Мытищи, 2016. 102 с. [Smirnov A.I. Influence of a Low Frequency Electromagnetic Field on Seed Germination and Growth of Scots Pine Seedlings in Nurseries of Mixed Forest Zone: Cand. Agric. Sci. Diss. Mytischi, 2016. 102 p.].

12. Смирнов А.И., Орлов Ф.С., Дроздов И.И. Влияние низкочастотного электромагнитного поля на прорастание семян и рост сеянцев сосны обыкновенной и ели европейской // Изв. вузов. Лесн. журн. 2015. № 3. С. 53-58. [Smirnov A.I., Orlov F.S., 
Drozdov I.I. Influence of Low Frequency Electromagnetic Field on Seed Germination and Growth of Seedlings of Scots Pine and Norway Spruce. Lesnoy Zhurnal [Russian Forestry Journal], 2015, no. 3, pp. 53-58]. DOI: 10.17238/issn0536-1036.2015.3.53, URL: http://lesnoizhurnal.ru/upload/iblock/ad1/smirnov.pdf

13. Смирнов А.И., Орлов Ф.С., Беляев В.В., Аксенов П.А. Влияние низкочастотного электромагнитного поля на биометрические характеристики сеянцев сосны обыкновенной (Pinus sylvestris L.) // Изв. вузов. Лесн. журн. 2019. № 2. С. 78-85. [Smirnov A.I., Orlov F.S., Belyaev V.V., Aksenov P.A. Influence of Low-Frequency Electromagnetic Field on Biometric Parameters of Scots Pine (Pinus sylvestris L.) Seedlings. Lesnoy Zhurnal [Russian Forestry Journal], 2019, no. 2, pp. 78-85]. DOI: 10.17238/issn05361036.2019.2.78, URL: http://lesnoizhurnal.ru/upload/iblock/30f/78 85.pdf

14. Crous J.W. Use of Hydrogels in the Planting of Industrial Wood Plantations. Southern Forests: a Journal of Forest Science, 2017, vol. 79, iss. 3, pp. 197-213. DOI: $10.2989 / 20702620.2016 .1221698$

15. De Lucas M., Etchhells J.P. Xylem. Methods and Protocols. New York, Humana Press, 2017. 262 p. DOI: 10.1007/978-1-4939-6722-3

16. Fischer G., Tausz M., Köck M., Grill D. Effect of Weak 16²/3 Hz Magnetic Fields on Growth Parameters of Young Sunflower and Wheat Seedlings. Bioelectromagnetics, 2004, vol. 25, iss. 8, pp. 638-641. DOI: 10.1002/bem.20058

17. Mudhanganyi A., Maravanyika C., Ndagurwa H.G.T., Mwase R. The Influence of Hydrogel Soil Amendment on the Survival and Growth of Newly Transplanted Pinus patula Seedlings. Journal of Forestry Research, 2018, vol. 29, iss. 1, pp. 103-109. DOI: 10.1007/s11676-017-0428-1

18. Sarvaš M., Pavlenda P., Takáčová E. Effect of Hydrogel Application on Survival and Growth of Pine Seedlings in Reclamations. Journal of Forest Science, 2007, vol. 53, iss. 5, pp. 204-209.

19. Schweingruber F.H. Wood Structure and Environment. Berlin, Heidelberg, Springer-Verlag, 2007. 279 p. DOI: 10.1007/978-3-540-48548-3

20. Viero P.W.M., Little K.M. A Comparison of Different Planting Methods, Including Hydrogels, and Their Effect on Eucalypt Survival and Initial Growth in South Africa. Southern African Forestry Journal, 2006, vol. 208, iss. 1, pp. 5-13. DOI: $\underline{10.2989 / 10295920609505256}$

\title{
ЭФФЕКТИВНОСТЬ ВЛИЯНИЯ НИЗКОЧАСТОТНОГО ЭЛЕКТРОМАГНИТНОГО ПОЛЯ И ГИДРОГЕЛЯ НА ПРИЖИВАЕМОСТЬ И РОСТ ОДНОЛЕТНИХ СЕЯНЦЕВ ДУБА КРАСНОГО (Quercus rubra L.)
}

\author{
А.И. Смирнов ${ }^{1}$, канд. с.-х. наук; ORCID: https://orcid.org/0000-0001-9530-6210 \\ Ф.C. Орлов ${ }^{1}$, канд. с.-х. наук; ORCID: https://orcid.org/0000-0002-8772-4428 \\ П.А. Аксенов ${ }^{2}$, канд. с.-х. наук, дои.; ResearcherID: H-1352-2019, \\ ORCID: https://orcid.org/0000-0002-1716-7726 \\ Ю.В. Яськов , директор Донского лесхоза; \\ ORCID: https://orcid.org/0000-0002-2140-9169 \\ ${ }^{1}$ ООО «Разносервис», Лихов пер., д. 10, Москва, Россия, 127051; e-mail: 364-27-37@mail.ru, \\ ap-6@yandex.ru \\ ${ }^{2}$ Мытищинский филиал МГТУ им. Н.Э. Баумана, ул. 1-я Институтская, д. 1, г. Мыти- \\ щи, Московская область, Россия, 141005; e-mail: axenov.pa@mail.ru, \\ forestmaster@yandex.ru

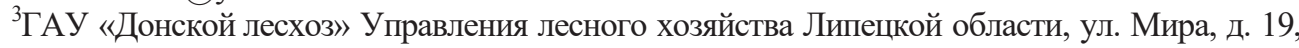
c. Донское, Задонский р-н, Липецкая обл., Россия, 99240; e-mail: forester48@mail.ru

В настоящей работе представлены результаты исследования, которое проводилось в лесном питомнике Донского лесхоза Управления лесного хозяйства Липецкой области. Цель исследования определить как гидрогель «Эвабиона» и низкочастотное электромагнитное поле (ЭМП) влияют на приживаемость и рост однолетних сеянцев дуба 
красного в открытом грунте питомника. В работе приведена технология создания посадочного материала дуба красного с повышенными показателями приживаемости опытных образцов и их биометрических характеристик: высота сеянца, диаметр сеянца у корневой шейки, масса корней и надземной части в воздушно-сухом состоянии после высушивания в течение 15 дней. Обработка однолетних сеянцев дуба красного низкочастотным электромагнитным полем проводилась по авторской технологии ПОСЭП (предпосевная обработка семян и сеянцев электромагнитным полем). В постановке опытов применялся гидрогель «Эвабиона», полимерный влагоудерживатель, который при внесении в почву, абсорбирует и удерживает большое количество влаги в зоне ризосферы растений. Способность гранул гидрогеля к разбуханию-сжатию улучшает структуру и дренаж почв, повышая условия аэрации и фильтрации воды, сохраняет свои влагоудерживающие свойства в течение нескольких лет. Полученные результаты исследования свидетельствуют о явном положительном влиянии обработки электромагнитным полем и гидрогелем, так как отмечено существенное увеличение приживаемости опытных образцов сеянцев дуба по отношению к контролю, также в рамках исследования, в конце вегетационного сезона в лаборатории кафедры лесных культур, селекции и дендрологии Мытищинского филиала МГТУ им. Н.Э. Баумана был проведен сравнительный гистометрический анализ поперечных срезов контрольных и опытных стволиков сеянцев дуба. Результаты этого исследования показали, что электромагнитное поле и гидрогель могут оказывать влияние на анатомическое строение сеянцев, улучшая их качественные характеристики. Таким образом, предпосадочная обработка сеянцев дуба низкочастотным электромагнитным полем и применение гидрогеля показали эффективность данных приемов для увеличения приживаемости сеянцев и получения качественного посадочного материала дуба красного в лесных питомниках.

Для цитирования: Smirnov A.I., Orlov F.S., Aksenov P.A., Yaskov Yu.V. The Effectiveness of Low Frequency Electromagnetic Field and Hydrogel Influence on Survival Rate and Growth of Red Oak (Quercus rubra L.) Annual Seedlings // Изв. вузов. Лесн. журн. 2020. № 5. C. 81-89. DOI: 10.37482/0536-1036-2020-5-81-89

Ключевые слова: низкочастотное электромагнитное поле, технология ПОСЭП, гидрогель, сеянцы дуба красного, гистометрический анализ.

Поступила 16.01.20 / Received on January 16, 2020 